\title{
A Review of the Risk Factors Associated With Poor Outcomes in Patients With Coronavirus Disease 2019
}

\author{
Muhammad Hanif ${ }^{1}$, Muhammad Adnan Haider ${ }^{2}$, Qianlan $\mathrm{Xi}^{3}{ }^{3}$, Mukarram Jamat Ali ${ }^{4}$, Muhammad Umer \\ Ahmed ${ }^{5}$ \\ 1. Medicine, Khyber Medical College Peshawar, Hayatabad Medical Complex, Peshawar, PAK 2. Internal Medicine, \\ Allama Iqbal Medical College/Jinnah Hospital, Lahore, PAK 3. Internal Medicine, West China Hospital, Sichuan \\ University, Chengdu, CHN 4. Medicine, King Edward Medical University, Lahore, PAK 5. Internal Medicine, Ziauddin \\ University, Karachi, PAK
}

Corresponding author: Qianlan Xi, qianlanxi55@gmail.com

\begin{abstract}
The global pandemic of coronavirus disease 2019 (COVID-19) and its rapid spread throughout the globe is of much concern. With little known about the peculiar virus and the changing mortality and morbidity, we attempt to review the risk factors associated with significant outcome.

We conducted a review of the information available in medical journals published on COVID-19 risk factors associated with poor outcomes using PubMed ${ }^{\circledR}$, Google Scholar, and material published online. The risk factors associated with poor outcome were kept in particular consideration. A total of 96 articles were thoroughly reviewed and analyzed so as to highlight the risk factors and the subsequent disease presentation that were present in patients with COVID-19. With little data available in this regard, emphasis and consideration of risk factors might help health care workers preclude the worst outcome. From the aforementioned search we can conclude that the most prevalent risk factors were reported to be hypertension followed by diabetes. In terms of mortality, age greater than 65 was the most significant risk factor. Among non-survivors, coagulation profile including d-dimers, prothrombin time, and inflammatory markers like erythrocyte sedimentation rate (ESR), C-reactive protein (CRP), and serum ferritin levels were very deranged. Much emphasis and consideration in relation to risk factors must be deliberated by health care workers so as to prevent severe outcomes and mitigate appropriate treatment modalities.
\end{abstract}

Received 08/30/2020 Review began 09/01/2020 Review ended 09/06/2020 Published 09/10/2020

() Copyright 2020 Hanif et al. This is an open access article distributed under the terms of the Creative Commons Attribution License CC-BY 4.0., which permits unrestricted use, distribution, and reproduction in any medium, provided the original author and source are credited.

Categories: Internal Medicine, Infectious Disease, Other

Keywords: covid-19, sars-cov-2, risk factors, co-morbidities, predictors, diabetes mellitus, hypertension

\section{Introduction And Background}

Coronavirus disease (COVID-19) caused by the severe acute respiratory syndrome coronavirus 2 (SARS-CoV2), initially began in Wuhan, China and now has been declared a global pandemic by the World Health Organization on March 11th, 2020 [1,2]. As the COVID-19 pandemic rages on (May 2020), there is an urgent need for clinical and laboratory predictors of severe and fatal disease. Here, we review the possible predictors of mortality for COVID-19 to help clinical professionals in the stratification of patients at an enhanced risk of developing severe disease and to discriminate between those at high or low risk of mortality.

\section{Review}

The various predictors of mortality associated with COVID-19 are shown in Table 1 and Table 2 and discussed below. 


\section{Cureus}

\begin{tabular}{|l|l|}
\hline Sr. \# & PREDICTORS \\
\hline 1. & Age \\
\hline 2. & Hematologic Biomarkers \\
3. & Biochemical markers \\
4. & Inflammatory biomarkers \\
5. & Coagulation profile \\
6. & Cerebrovascular Co-morbidities \\
7. & Hypertension \\
\hline 8. & Diabetes Mellitus \\
\hline
\end{tabular}

TABLE 1: Illustrates the predictors of mortality in patients with coronavirus disease 2019 (COVID19)

\begin{tabular}{|c|c|c|c|}
\hline PREDICTORS & AUTHORS & STUDY DESCRIPTION & $\begin{array}{l}\text { STUDY } \\
\text { TYPE/GEOGRAPHY }\end{array}$ \\
\hline AGE & $\begin{array}{l}\text { 1.Yang X, et al. } \\
\text { 2.Mehra MR, et } \\
\text { al. 3.Hu L, et al. } \\
\text { 4.Du RH, et al. } \\
\text { 5.Wang K, et al. } \\
\text { 6.Wang K et al. } \\
\text { 7.Nikpouraghdam } \\
\text { M, et al. 8.Leung } \\
\text { C, et al. } 9 \\
\text { Martins-Filho PR, } \\
\text { et al. }\end{array}$ & $\begin{array}{l}\text { 1. COVID-19 non-survivors were older in comparison to survivors. } 2 \text {. Age } \\
\text { older than } 65 \text { years was associated with an increased risk of death in } \\
\text { COVID-19 patients i.e. increased mortality by } 10 \% \text { with odds ratio (OR) } 1.93 \text {. } \\
\text { 3. Age over } 65 \text { predicted unfavorable clinical outcomes including death with } \\
\text { OR=3.549 AND p<0.001. } 4 \text {. Mortality due to COVID- } 19 \text { pneumonia was } \\
\text { concentrated in people ages } \geq 65 \text { years. } 5 \text {. The mean age of the non-survivor } \\
\text { group i.e. } 65.6 \pm 12.6 \text { was remarkably higher than the mean age of the } \\
\text { survivor group } 46.0 \pm 14.4 \text { years. } 6 \text {. Higher hazard ratio (HRs) or } 15 \text {-day in- } \\
\text { hospital death were associated with age older than } 65 \text { years i.e. HR } 1.962 .7 \text {. } \\
\text { For a one-year increase in the age, the odds of death in patients suffering } \\
\text { from COVID } 19 \text { increased significantly i.e. OR=1.05 } 8 \text {. Deceased had mean } \\
\text { age of } 75 \text { years in comparison to survivors i.e. mean age } 68 \text { years, p=0.017. } \\
\text { 9. Increased risk for in-hospital death in older patients i.e. MD=13.8 years. }\end{array}$ & $\begin{array}{l}\text { 1.Retrospective, } \\
\text { observational } \\
\text { study/China. } \\
\text { 2.Retrospective, } \\
\text { observational } \\
\text { study/Asia, Europe } \\
\text { and North America. } \\
\text { 3.Retrospective } \\
\text { study/China. 4.Multi- } \\
\text { center observational } \\
\text { study/China. } \\
\text { 5.Retrospective } \\
\text { cohort study/China. } \\
\text { 6.Observational } \\
\text { cohort study/China. } \\
\text { 7.Retrospective } \\
\text { study/Iran. } \\
\text { 8.Retrospective } \\
\text { study/China. } \\
\text { 9.Retrospective } \\
\text { study/China. }\end{array}$ \\
\hline \multirow[t]{2}{*}{$\begin{array}{l}\text { HEMATOLOGICAL } \\
\text { BIOMARKERS }\end{array}$} & $\begin{array}{l}\text { 1.Ruan Q, et al. } \\
\text { 2.Zhou F, et al. } \\
\text { 3.Wang K, et al. } \\
\text { 4.Hu L, et al. } \\
\text { 5.Wang K, et al. } \\
\text { 6.Liu Y, et al. } \\
\text { 7.Henry BM, et } \\
\text { al. 8.Martins- } \\
\text { Filho PR, et al. }\end{array}$ & $\begin{array}{l}\text { 1. Significant differences exist in white blood cell (WBC) counts, absolute } \\
\text { values of lymphocytes, platelets between non-survivor group and survivor } \\
\text { group. 2. Significantly higher count in baseline lymphocyte in survivors than } \\
\text { non-survivors. 3. Severe lymphopenia was associated with increase } \\
\text { mortality in COVID-19 patients. } 4 \text {. Leukocytosis and neutrophilia predicted } \\
\text { unfavorable clinical outcomes in COVID-19 patients with p<0.001. 5. WBCs, } \\
\text { specifically neutrophils, were considerably higher whereas lymphocytes } \\
\text { were remarkably lower in the non-survivor group as compared to the } \\
\text { survivor group. } 6 \text {. There was an } 8 \% \text { higher risk of in-hospital mortality for } \\
\text { each unit increase in neutrophil to lymphocyte ratio (NLR) and the patients } \\
\text { in the highest NLR tertile had a } 15.04 \text {-fold higher risk of death. } 7 \text {. COVID-19 } \\
\text { patients who had fatal outcomes were noted to have a significantly } \\
\text { increased WBC count and a decreased amount of both, lymphocytes and } \\
\text { platelets, as compared to those patients who survived. } 8 \text {. COVID-19 non- } \\
\text { survivor patients had increased levels of white blood cells and neutrophils in } \\
\text { comparison to survivors. }\end{array}$ & $\begin{array}{l}\text { 1.Retrospective } \\
\text { study/China. } \\
\text { 2.Retrospective } \\
\text { cohort study/China. } \\
\text { 3.Retrospective } \\
\text { study/China. } \\
\text { 4.Retrospective } \\
\text { study/China. } \\
\text { 5.Observational } \\
\text { cohort study/China. } \\
\text { 6.Retrospective } \\
\text { cohort study/China. } \\
\text { 7.Meta-analysis. } \\
\text { 8.Retrospective } \\
\text { study/China. }\end{array}$ \\
\hline & & 1. Serum total bilirubin, blo & \\
\hline
\end{tabular}




\begin{tabular}{|c|c|c|c|}
\hline $\begin{array}{l}\text { BIOCHEMICAL } \\
\text { MARKERS }\end{array}$ & $\begin{array}{l}\text { 1.Ruan Q, et al. } \\
\text { 3.Whou F, et al. } \\
\text { 4.Henry BM, et } \\
\text { al. 5.Martins- } \\
\text { Filho PR, et al. } \\
\text { 6.Santoso A, et } \\
\text { al. }\end{array}$ & $\begin{array}{l}\text { myoglobin and cardiac troponin were higher in non-survivors in comparison } \\
\text { to survivors. 2. Cardiac troponin I, creatinine, alanine aminotransferase } \\
\text { (ALT), and lactate dehydrogenase (LDH) were elevated in non-survivors } \\
\text { compared with survivors throughout the clinical course and showed a } \\
\text { significant increase with the progression of illness. 3. Creatinine, blood urea } \\
\text { nitrogen (BUN), ALT, aspartate aminotransferase (AST), LDH, and blood } \\
\text { ammonia were remarkably higher whereas GFR and serum albumin were } \\
\text { significantly lower in the non-survivor group. } 4 \text {. Non-survivor COVID-19 } \\
\text { patients had significantly elevated cardiac troponin levels, liver enzymes } \\
\text { (ALT and AST) and renal biomarkers (urea nitrogen, creatinine) at } \\
\text { presentation. 5. Non-surviving patients had increased levels of creatinine, } \\
\text { creatine kinase, hypersensitive cardiac troponin I, lactate dehydrogenase, } \\
\text { and decreased level of albumin in comparison to survivors. } 6 \text {. There was a } \\
\text { strong association of cardiac injury with higher mortality of COVID-19 } \\
\text { patients, defined as high sensitive cardiac troponin I>99 th percentile. }\end{array}$ & $\begin{array}{l}\text { 1.Retrospective } \\
\text { study/China. } \\
\text { 2.Retrospective } \\
\text { cohort study/China. } \\
\text { 3.Observational } \\
\text { Cohort study/China. } \\
\text { 4.Meta-analysis. } \\
\text { 5.Retrospective } \\
\text { study/China. 6.Meta- } \\
\text { analysis. }\end{array}$ \\
\hline $\begin{array}{l}\text { INFLAMMATORY } \\
\text { MARKERS }\end{array}$ & $\begin{array}{l}\text { al. 2.Wang ZL, et } \\
\text { al. 3.Zhou F et al. } \\
\text { 4.Lui W, et al. }\end{array}$ & $\begin{array}{l}\text { 1. Non-survivors had high level of C-reactive protein } 86.4 \mathrm{mg} / \mathrm{L}^{-1}(39.9-105.5) \\
\text { compared to survivors } 36.0 \mathrm{mg} / \mathrm{L}^{-1}(19.3-91.0) \text { with } \mathrm{p}=0.012 .2 . \mathrm{SpO}_{2}<90 \% \\
\text { was associated with a higher level of erythrocyte sedimentation rate }(\mathrm{ESR}) \\
\text { and C-reactive proteins }(\mathrm{CRP}) \text { in comparison with the patients having } \mathrm{SpO}_{2} \geq \\
90 \% \text { ( } \mathrm{p}<0.001) \text {. 3. Non-survivors had high level of interleukin } 6 \text {, } \\
\text { procalcitonin, serum ferritin, C-reactive protein in comparison with } \\
\text { survivors. } 4 \text {. C-reactive protein was also reportedly higher }[38.9 \mathrm{mg} / \mathrm{L}(14.3- \\
64.8)] \text { in unstable patients as compared to stable patients }[38.9 \mathrm{mg} / \mathrm{L}(14.3- \\
64.8)], \mathrm{p}<0.024 \text {. }\end{array}$ & $\begin{array}{l}\text { 1.Prospective cohort } \\
\text { study/China. } \\
\text { 2.Retrospective } \\
\text { cohort study/China. } \\
\text { 3.Retrospective } \\
\text { cohort study/China. } \\
\text { 4.Retrospective } \\
\text { cohort study/China. }\end{array}$ \\
\hline $\begin{array}{l}\text { COAGULATION } \\
\text { PROFILE }\end{array}$ & $\begin{array}{l}\text { 1.Tang } \mathrm{N} \text {, et al. } \\
\text { 2.Zhang } \mathrm{L} \text {, et al. } \\
\text { 3.Zhou } \mathrm{F} \text {, et al. }\end{array}$ & $\begin{array}{l}\text { 1. Non-survivors COVID-19 patients had a higher level of D-dimers, } \\
\text { prothrombin time and fibrin degradation products (FDPs) as compared to } \\
\text { the survivors. } 2 \text {. Higher levels of } D \text {-dimers were associated with an } \\
\text { increased mortality in patients with COVID-19, } p<0.001 \text {. 3. Non survivors } \\
\text { COVID-19 patients had higher level of D-dimers }[5 \cdot 2 \mu \mathrm{g} / \mathrm{mL}(1 \cdot 5-21 \cdot 1)] \text { as } \\
\text { compared to survivors }[0.6 \mu \mathrm{g} / \mathrm{mL}(0 \cdot 3-1 \cdot 0)],(p<0.0001) \text {. }\end{array}$ & $\begin{array}{l}\text { 1.Retrospective } \\
\text { cohort study/China } \\
\text { 2.Retrospective } \\
\text { cohort study/China. } \\
\text { 3.Retrospective } \\
\text { cohort study/China. }\end{array}$ \\
\hline $\begin{array}{l}\text { CEREBROVASCULAR } \\
\text { COMORBIDITIES }\end{array}$ & $\begin{array}{l}\text { 1.Mao L, et al. } \\
\text { 2.Tralhao A, et al. } \\
\text { 3.Avula A, et al. } \\
\text { 4.Lodigiani C, et } \\
\text { al. } 5 . \text { Yang } \mathrm{X} \text {, et } \\
\text { al. 6.Madjid M, et } \\
\text { al. 7.Aggarwal G, } \\
\text { et al. }\end{array}$ & $\begin{array}{l}\text { 1. Patients with more severe infection had neurologic manifestations, } \\
\text { including acute cerebrovascular diseases ( } 5.7 \%) \text {. } 2 \text {. The incidence of acute } \\
\text { stroke was } 0.71 \% \text { of pooled inpatients of COVID-19. 3. Four COVID- } 19 \\
\text { patients with acute stroke as a presenting symptom. } 4.2 .5 \% \text { of patients } \\
\text { admitted to the hospital with laboratory-proven COVID-19 were diagnosed } \\
\text { with ischemic stroke. } 5 \text {. Comorbidities among the } 2 \text { groups of survivors vs } \\
\text { non-survivors were } 40 \% \text { ( } 20 \% \text { vs } 53 \%) \text {, with cerebrovascular disease ( } 0 \% \text { vs } \\
22 \% \text { ). } 6 \text {. Cerebrovascular disease was associated with mortality of COVID- } \\
19 \text { patients. } 7.2 .5 \text {-fold increase in odds of severe COVID-19 illness with a } \\
\text { history of cerebrovascular disease. }\end{array}$ & $\begin{array}{l}\text { 1.Retrospective } \\
\text { cohort study/China. } \\
\text { 2.Meta-analysis. } \\
\text { 3.Case series/China. } \\
\text { 4.Retrospective } \\
\text { cohort study/Italy. } \\
\text { 5.Retrospective, } \\
\text { observational } \\
\text { study/China. } \\
\text { 6.Review article. } \\
\text { 7.Meta-analysis. }\end{array}$ \\
\hline \multirow[t]{2}{*}{ HYPERTENSION } & $\begin{array}{l}\text { 1.Guan et al. } \\
\text { 2.Guan WJ et al. } \\
\text { 3.Hu Y, et al. } \\
\text { 4.Liu Z, et. al. } \\
\text { 5.Zhou F, et al. } \\
\text { 6.Li J, et. al. } \\
\text { 7.Lippi G, et. al. } \\
\text { 8.Ruan Q, et al. } \\
\text { 9.Zheng Z, et. al. }\end{array}$ & 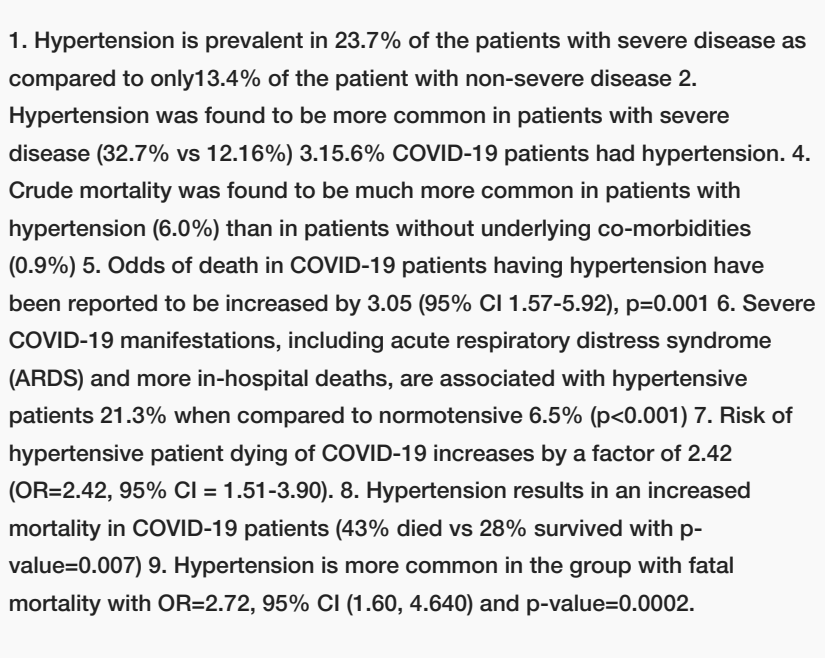 & $\begin{array}{l}\text { 1.Retrospective } \\
\text { study/China. } \\
\text { 2.Retrospective } \\
\text { cross-sectional } \\
\text { study/China. 3.Meta- } \\
\text { analysis. } \\
\text { 4.Retrospective } \\
\text { cross-sectional } \\
\text { study/China. } \\
\text { 5.Retrospective } \\
\text { cohort study/China. } \\
\text { 6.Retrospective } \\
\text { cohort study/China. } \\
\text { 7.Meta-analysis. } \\
\text { 8.Retrospective } \\
\text { study/China. 9.Meta- } \\
\text { analysis. }\end{array}$ \\
\hline & & $\begin{array}{l}\text { 1. COVID patients who had underlying diabetes had a higher odds of death } \\
\left.\text { (OR } 3.21,95 \% \mathrm{CI} 1.82-5.64, \mathrm{p}<0.0001, \mathrm{I}^{2}=16 \%\right) \text {. } 2 \text {. DM is associated with }\end{array}$ & $\begin{array}{l}\text { 1.Meta-analysis. } \\
\text { 2.Meta-analysis. }\end{array}$ \\
\hline
\end{tabular}




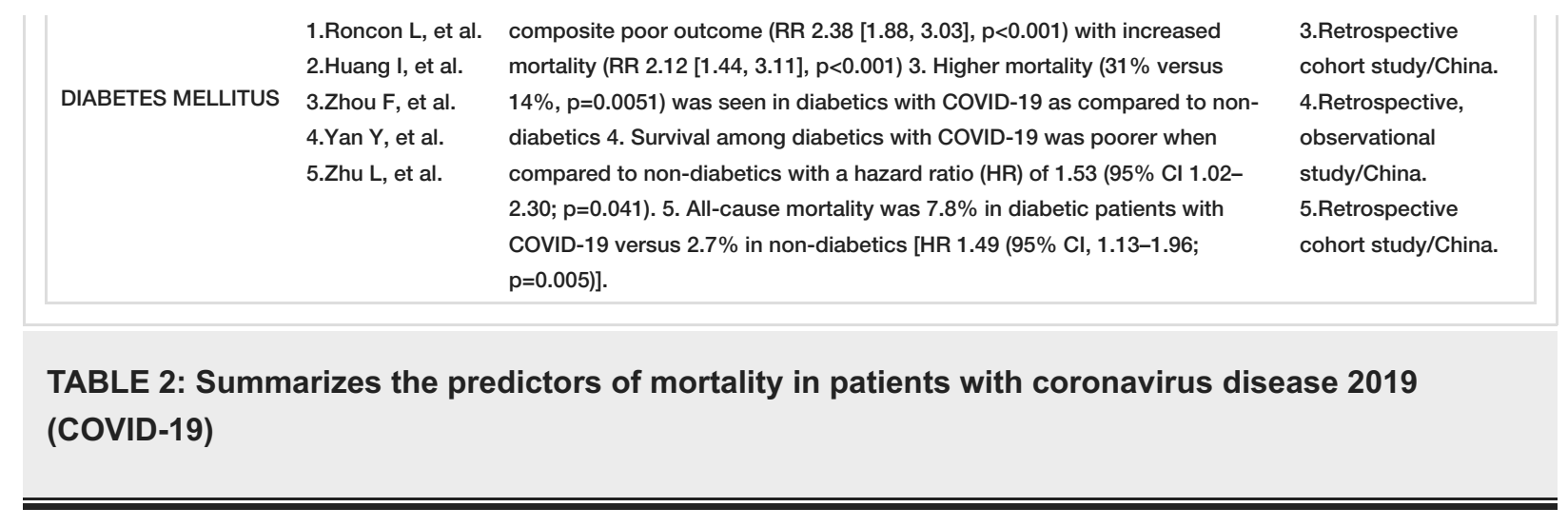

Age

It is well documented that advanced age is a predictor of mortality in patients with COVID-19, especially in those over 65 years of age. Yang et al. [3] reported that non-survivors were older than survivors (mean age $=64.6 \mathrm{vs} .51 \cdot 9$, respectively) and were more likely to have chronic medical conditions, compared to survivors. Mehra et al. [4] found that age greater than 65 years was independently associated with an increased risk of in-hospital death (mortality of $10.0 \%$, vs. $4.9 \%$ among those less than equal to 65 years of age; odds ratio [OR], 1.93; 95\% confidence interval [CI], 1.60 to 2.41). Recently, the results of Hu et al. [5] indicated that age, in patients over 65 years, was a predictor of unfavorable clinical outcomes, including death $(\mathrm{OR}=3.546$; $95 \% \mathrm{CI}=1.626-7.733$, $\mathrm{p}<0.001)$. Mortality due to COVID-19 pneumonia was higher in people aged $>65$ years in a multi-center observational study of 109 decedents with COVID-19 pneumonia carried out by Du et al. [6]. A cohort study by Wang et al. [7] found that the mean age of the non-survivor group was remarkably higher than that of the survivor group. Wang et al. [8], using a multivariate Cox proportional hazards regression model, showed that higher hazard ratios (HRs) for 15-day in-hospital death were associated with age $>65$ years. Nikpouraghdam et al. [9], in Iran, also demonstrated that for each oneyear increase in age, the odds of death increased by $5 \%(\mathrm{OR}=1.05$; $95 \% \mathrm{CI}=1.04-1.06)$. Similarly, Leung et al. [10] found a significant high mortality ratio in COVID-19 patients aged $\geqslant 80$ years. A quantitative evidence synthesis of clinical and laboratory factors in 852 patients, from Martins-Filho et al. [11], showed an increased risk of in-hospital death in older patients.

\section{Hematological biomarkers}

Ruan et al. [12] found that there were significant differences in total white blood cell (WBC) counts, absolute values of lymphocytes, and platelets between the non-survivor and survivor groups, from a retrospective multicenter study in Wuhan, China. In comparison to non-survivors, there was significant higher lymphocyte count in survivors. In addition, Zhou et al. [13] found that the lymphocyte count was lowest on day seven after onset of illness and improved during hospitalization. Severe lymphopenia was also observed in non-survivors. The most influential marker of risk, according to Wang et al. [7], was severe lymphopenia $(<0.5 \times 109 / \mathrm{L})$, which was associated with higher mortality $(\mathrm{HR}=4.410)$ compared to patients with a lymphocyte count $>0.5 \times 109 / \mathrm{L}$. Recently, a retrospective review of 323 hospitalized patients with COVID-19 in Wuhan, conducted by Hu et al. [5], indicated that leukocytosis ( $>10 \times 109 / \mathrm{L}, \mathrm{p}<0.001)$ and neutrophilia $(>75$ $\times 109 / \mathrm{L}, \mathrm{p}<0.001)$ predicted unfavorable clinical outcomes. Similarly, in comparison to the survivor group, the non-survivor group was found to have high higher total WBC and neutrophil counts and lower lymphocyte counts as reported by Wang, et al. [8]. Liuet et al. [14] reported that there was an $8 \%$ higher risk of in-hospital mortality in patients with increased neutrophil-to-lymphocyte ratio (NLR), and patients in the highest NLR had a 15.04-fold higher risk of death. A meta-analysis from Henry et al. [15] also concluded that compared to survivors, non-survivors had significantly increased WBC counts and decreased lymphocyte and platelet counts. Quantitative evidence of clinical and laboratory factors in 852 patients, from MartinsFilho et al. [11], also showed that survivors had lower levels of white blood cells and neutrophils. Therefore, increased total WBC counts, as well as increased NLR, decreased lymphocytes, and decreased platelet counts are independent risk factors of in-hospital mortality in COVID-19 patients.

\section{Biochemical markers}

Ruan et al. [12] reported that total serum bilirubin, blood urea nitrogen (BUN), serum creatinine ( $\mathrm{Cr}$ ), myoglobin, and cardiac troponin were higher in non-survivors than survivors. In comparison to nonsurvivors, survivors were found to have low levels of cardiac troponin I, Cr, alanine aminotransferase (ALT), and lactate dehydrogenase (LDH) as reported by Zhou et al. [13]. Serum albumin was lower in non-survivors than in survivors. High-sensitivity cardiac troponin I $(>0.04 \mathrm{pg} / \mathrm{mL}, \mathrm{p}=0.02)$ was reported to predict unfavorable clinical outcomes. Wang et al. [8] also demonstrated that Cr, BUN, ALT, aspartate aminotransferase (AST), LDH, and blood ammonia were significantly higher, whereas GFR and serum albumin were significantly lower in the non-survivor group. A meta-analysis by Henry et al. [15] also found that non-survivors had significantly elevated levels of cardiac troponin, liver enzymes (ALT and AST), and renal biomarkers (BUN, Cr) at presentation. Martins-Filho et al. [11] also found that non-survivor patients had increased levels of Cr, creatine kinase, high-sensitivity cardiac troponin I, LDH, and decreased 
levels of albumin. A meta-analysis of 2389 patients from Santoso et al. [16] demonstrated that cardiac injury was associated with higher mortality, which was defined as high-sensitivity cardiac troponin I>99thpercentile.

\section{Inflammatory biomarkers}

Inflammation is the body's innate immune response to various kinds of injury or insult and during this process a number of proteins are released into the bloodstream. Based on current clinical evidence, inflammatory biomarkers such as C-reactive protein (CRP), serum ferritin, procalcitonin, interleukins, and the erythrocyte sedimentation rate (ESR), play key roles as predictors in evaluating severity and mortality in COVID-19 patients [17].

Rong-Hui et al. conducted a prospective study to evaluate the different predictors of mortality in 179 COVID-19 patients and concluded that non-survivors $(n=21)$ had a higher level of $C$-reactive protein $($ mean $=86.4 \mathrm{mg} / \mathrm{L}-1$; range $=39.9-105.5)$ than survivors $(\mathrm{n}=158)($ mean=36.0 $\mathrm{mg} / \mathrm{L}-1$; range=19.3-91.0) with $\mathrm{p}=0.012[18]$.

In another study, Wang et al. evaluated the clinical course of 69 patients with COVID-19 and established that peripheral capillary oxygen saturation (SpO2) $<90 \%$ was associated with a higher rate of erythrocyte sedimentation and CRP in comparison with patients with $\mathrm{SpO} 2 \geqslant 90 \%(\mathrm{p}<0.001)$ [19].

In a retrospective study, Fei Zhou et al. concluded that non-survivors had a higher level of interleukin 6 (IL6) $($ mean $=11 \cdot 0 \mathrm{pg} / \mathrm{mL}$; range=7.5-14.4) compared to survivors (mean=6.3 pg/mL; range=5.0-7.9; $\mathrm{p}<0.0001$ ). They also found a higher level of serum ferritin (mean=1435.3 $\mu \mathrm{g} / \mathrm{L}$; range=728.9-2000.0) in non-survivors compared with survivors (mean=503.2 $\mu \mathrm{g} / \mathrm{L}$; range $=264.0-921.5 ; \mathrm{p}<0.0001$ ) [13]. CRP was also reported to be higher $($ mean=38.9 mg/L; range=14.3-64.8) in unstable patients, compared to stable patients (mean: 10.6 $\mathrm{mg} / \mathrm{L} ; 1.9-33.1 ; \mathrm{p}=0.024)$, in a study conducted by Lui et al. [20].

In light of the above-mentioned studies, it is evident that high levels of CRP, ESR, IL-6, procalcitonin, and serum ferritin are associated with worse outcomes and increased mortality of patients with COVID-19.

\section{Coagulation profile}

Coagulation abnormalities, ranging from a small decrease in platelet count to disseminated intravascular coagulation, are associated with septicemia, as well as multisystem organ dysfunction syndrome (MODS) [21]. Many coagulative abnormalities have also been observed with SARS-CoV-2 infection, and have been proposed to be associated with increased mortality in COVID-19 patients.

Tang et al. concluded, from a retrospective study involving patients with COVID-19, that non-survivors had higher levels of D-dimers and fibrin degradation products (FDPs), and a raised prothrombin time, compared to survivors $(\mathrm{p}<0.001)$ [22]. In another retrospective study, Zhang et al. established that high levels of Ddimers are associated with increased mortality in patients with COVID-19 $(p<0.001)$ [23].

Similarly, Zhouet et al. reported that non-survivors had higher levels of D-dimers (mean=5.2 $\mu \mathrm{g} / \mathrm{mL}$; range $=1 \cdot 5-21 \cdot 1)$ than survivors (mean $=0 \cdot 6 \mu \mathrm{g} / \mathrm{mL}$; range $=0 \cdot 3-1 \cdot 0 ; \mathrm{p}<0.0001)[13]$.

\section{Cerebrovascular co-morbidities}

It has been reported that pre-existing cerebrovascular disease, and stroke after diagnosis of COVID-19, are both predictors of mortality, which might be related to hypercoagulable state from clotting variables and platelet count $[24,25,26]$. Neurological manifestations including acute cerebrovascular diseases $(5.7 \%)$, were found more in patients with severe condition with COVID-19 as reported Mao et al. [27]. A meta-analysis of observational studies from Tralhao et al. [28] reported that the incidence of acute stroke was $0.71 \%$ in pooled inpatients. Avula et al. [29] reported a series of four COVID-19 patients with acute stroke as a presenting symptom. Lodigiani et al. [30] found that $2.5 \%$ of patients admitted to the hospital with laboratory-proven COVID-19 were diagnosed with ischemic stroke. In a single-centered, retrospective, study conducted by Yang et al. [3], the mortality rate was $61.5 \%$ by four weeks in 52 critically ill patients with COVID-19. From the review of Madjid et al. [31], cerebrovascular diseases were found to be one of the most important factors associated with mortality in patients with COVID-19. A pooled analysis of published literature from Aggarwal et al. [32], with a sample of 1829 confirmed COVID-19 patients, showed a $\sim 2.5$-fold increase in odds of severe COVID-19 illness with a history of cerebrovascular disease. While a trend was observed, there was no statistically significant association between stroke and mortality in patients with COVID-19 infection.

\section{Hypertension}

Hypertension is the single most prevalent comorbid condition in COVID-19 patients, as shown in a study from China where $15 \%$ of the patients had hypertension [33]. Similarly, a nationwide survey, a metaanalysis, and a cross-sectional study from China showed that 16.9\% [34], 15.6\% [35], and 12.6\% [36] of the 
COVID-19 patients had hypertension. However, two other studies showed that 30\% [13] and 30.7\% [37] had hypertension. These results are not surprising, as this proportion is quite similar to the general incidence of hypertension observed in the general Chinese population, which is $23.2 \%$ [38].

Many studies have shown that hypertension is a risk factor associated with increased ICU admission and mortality in COVID-19 patients. Hypertension was found in higher proportion in patients with severe COVID-19 (23.7\%) in comparison to non-severe (13.4\%) as showed by Guan et al. [33]. Hypertension was also associated with poor composite outcomes included in this study (35.8\% vs. $13.7 \%)$. Similarly, in another study, hypertension was more common in patients with severe disease (32.7\% vs.12.6\%) and hypertensive patients were found to have severe outcomes (invasive ventilations or death) in comparison to nonhypertensive (19.7\% vs. 5.9\%) [34]. Crude mortality was much more common in patients with hypertension (6.0\%) than in patients without underlying comorbidities (0.9\%) [36]. More severe COVID-19 manifestations, including acute respiratory distress syndrome (ARDS) and in-hospital death, are associated with hypertensive patients $(21.3 \%)$ than with normotensive patients $(6.5 \%, \mathrm{p}<0.001)$ [37]. A pooled analysis of 13 studies and 2893 patients concluded that the risk of hypertensive patients having severe COVID-19 was 2.5 times higher $(\mathrm{OR}=2.49 ; 95 \% \mathrm{CI}=1.98-3.12)$. Similarly, the risk of hypertensive patients dying of COVID-19 also increases 2.42 -fold $(\mathrm{OR}=2.42 ; 95 \% \mathrm{CI}=1.51-3.90)$ [39]. In an article stating that hypertension resulted in increased mortality in COVID-19 patients, $43 \%$ died and $28 \%$ survived ( $\mathrm{p}=0.07$ ) [12]. A meta-analysis showed that hypertension is more common in the critical/mortality group $(\mathrm{OR}=2.72 ; 95 \% \mathrm{CI}=1.60-4.640$; $\mathrm{p}=0.0002$ ) [40]. Odds of death in COVID-19 patients have been reported to be increased 3.05-fold by having hypertension (95\% CI=1.57-5.92; $\mathrm{p}=0.001)$ [13].

\section{Diabetes mellitus}

Diabetes mellitus, characterized by hyperglycemia and insulin resistance, is a chronic inflammatory condition that leads to increased end products of glycosylation, inflammatory cytokine production, and oxidative stress, resulting in tissue damage and increased risk of infections, and leading to morbidity and mortality $[41,42,43]$. People with diabetes are prone to respiratory tract infections such as influenza and pneumonia [44], and possibly COVID-19. Chronic inflammation, immune response impairment, increased coagulation activity, and (possibly) direct pancreatic damage caused by SARS-CoV-2 are potential underlying mechanisms [45].

In a study conducted on 1382 COVID-19 patients, diabetic patients were found to have increased risk of ICU admission $(\mathrm{OR}=2.79 ; 95 \% \mathrm{CI}=1.85-4.22 ; \mathrm{p}<0.0001 ; \mathrm{I} 2=46 \%)$ and also had a higher probability of death $(\mathrm{OR}=3.21 ; 95 \% \mathrm{CI}=1.82-5.64 ; \mathrm{p}<0.0001 ; \mathrm{I} 2=16 \%)$ [46].In a meta-analysis of 6452 patients from 30 different studies, Huang et al. concluded that diabetic COVID-19 patients were associated with increased mortality (relative risk $[R R]=2.12[1.44,3.11] ; \mathrm{p}<0.001)$, acute respiratory distress syndrome $(\mathrm{RR}=4.64[1.86,11.58]$; $\mathrm{p}=0.001)$, and disease progression $(\mathrm{RR}=3.31[1.08,10.14] ; \mathrm{p}=0.04)$ [47]. Similarly, a significantly higher mortality ( $31 \%$ versus $14 \%$; $=0.0051$ ) was seen in patients with diabetes with COVID-19 than in those without diabetes in a retrospective cohort study conducted in Wuhan [13].

In a retrospective, observational study, Yan et al. established that survival among those with DM was poorer, with COVID-19, compared to a non-DM group, with a hazard ratio (HR) of 1.53 (95\% CI=1.02-2.30; $\mathrm{p}=0.041$ ), after adjustment for age, sex, hypertension, cardiovascular disease, and cerebrovascular diseases [48]. Moreover, Zhu et al., in a retrospective study, found that all-cause mortality was $7.8 \%$ in DM patients with COVID-19 versus $2.7 \%$ in non-DM patients (HR=1.49; $95 \% \mathrm{CI}=1.13-1.96$; $\mathrm{p}=0.005$ ). Additionally, all-cause mortality was lower (1.1\%) in patients with tight glycemic control than in those with poorly controlled blood glucose levels (11.0\%) [49].

In conclusion, the existing literature is clearly showing increased mortality in diabetic patients compared to non-diabetic, especially in patients of advanced age. There is a need to develop novel ways to deliver healthcare to patients with DM using tele-health and for remote patient monitoring for tight glycemic control, without exposing them to unnecessary hazards.

\section{Conclusions}

From the aforementioned literature as summarized in Table 2, we can conclude that the most prevalent risk factor is hypertension followed by diabetes. In terms of mortality, age greater than 65 was the most significant. Amongst non-survivors coagulation profile including d-dimers, prothrombin time, and inflammatory markers like ESR, CRP, and serum ferritin levels were much deranged. Patients with diabetes mellitus, hypertension, cerebrovascular accidents, and age greater than 65 must be in particular managed at home in order to decrease unnecessary exposure at the hospital. From the above data we recommend that the patients with COVID-19 should initially be stratified and segregated on the basis of the above risk factors. Much emphasis and consideration in relation to risk factors must be deliberated by health care providers so as to prevent severe outcomes and mitigate appropriate treatment modalities.

\section{Additional Information}

\section{Disclosures}


Conflicts of interest: In compliance with the ICMJE uniform disclosure form, all authors declare the following: Payment/services info: All authors have declared that no financial support was received from any organization for the submitted work. Financial relationships: All authors have declared that they have no financial relationships at present or within the previous three years with any organizations that might have an interest in the submitted work. Other relationships: All authors have declared that there are no other relationships or activities that could appear to have influenced the submitted work.

\section{References}

1. Lu H, Stratton CW, Tang YW: Outbreak of pneumonia of unknown etiology in Wuhan, China: The mystery and the miracle. J Med Virol. 2020, 92:401-402. 10.1002/jmv.25678

2. Wang C, Horby PW, Hayden FG, Gao GF: A novel coronavirus outbreak of global health concern [published correction appears in Lancet 2020 Jan 29]. Lancet. 2020, 395:470-473. 10.1016/S0140-6736(20)30185-9

3. Yang X, Yu Y, Xu J, et al.: Clinical course and outcomes of critically ill patients with SARS-CoV-2 pneumonia in Wuhan, China: a single-centered, retrospective, observational study [published correction appears in Lancet Respir Med]. Lancet Respir Med. 2020, 26:475-481. 10.1016/S2213-2600(20)30079-5

4. Mehra MR, Desai SS, Kuy S, Henry TD, Patel AN: Cardiovascular disease, drug therapy, and mortality in Covid-19. N Engl J Med. 2020, 382:e102. 10.1056/NEJMoa2007621

5. Hu L, Chen S, Fu Y, et al.: Risk Factors Associated with Clinical Outcomes in 323 COVID-19 Hospitalized Patients in Wuhan, China [published online ahead of print, 2020 May 3]. Clin Infect Dis. 2020, 10.1093/cid/ciaa539

6. Du RH, Liu LM, Yin W, et al.: Hospitalization and critical care of 109 decedents with COVID-19 pneumonia in Wuhan, China. Ann Am Thorac Soc. 2020, 17: 10.1513/AnnalsATS.202003-2250C

7. Wang K, Zuo P, Liu Y, et al.: Clinical and laboratory predictors of in-hospital mortality in patients with COVID- 19: a cohort study in Wuhan, China [published online ahead of print, 2020 May 3]. Clin Infect Dis. 2020, 10.1093/cid/ciaa538

8. Wang K, Zhang Z, Yu M, Tao Y, Xie M: 15-day mortality and associated risk factors for hospitalized patients with COVID-19 in Wuhan, China: an ambispective observational cohort study. Intensive Care Med. 2020, 46:1472-1474. 10.1007/s00134-020-06047-w

9. Nikpouraghdam M, Jalali Farahani A, Alishiri G, et al.: Epidemiological characteristics of coronavirus disease 2019 (COVID-19) patients in IRAN: a single center study. J Clin Virol. 2020, 127:104378. 10.1016/j.jcv.2020.104378

10. Leung C: Risk factors for predicting mortality in elderly patients with COVID- 19: a review of clinical data in China. Mech Ageing Dev. 2020, 188:111255. 10.1016/j.mad.2020.111255

11. Martins-Filho PR, Tavares CSS, Santos VS: Factors associated with mortality in patients with COVID-19. A quantitative evidence synthesis of clinical and laboratory data. Eur J Intern Med. 2020, 953:620530165-5. 10.1016/j.ejim.2020.04.043

12. Ruan Q, Yang K, Wang W, Jiang L, Song J: Correction to: Clinical predictors of mortality due to COVID-19 based on an analysis of data of 150 patients from Wuhan, China. Intensive Care Med. 2020, 46:1294-1297. 10.1007/s00134-020-06028-Z

13. Zhou F, Yu T, Du R, et al.: Clinical course and risk factors for mortality of adult inpatients with COVID-19 in Wuhan, China: a retrospective cohort study [published correction appears in Lancet]. Lancet. 2020, 395:1054-1062. 10.1016/S0140-6736(20)30566-3

14. Liu Y, Du X, Chen J, et al.: Neutrophil-to-lymphocyte ratio as an independent risk factor for mortality in hospitalized patients with COVID-19. J Infect. 2020, 81:e6-e12. 10.1016/j.jinf.2020.04.002

15. Henry BM, de Oliveira MHS, Benoit S, Plebani M, Lippi G: Hematologic, biochemical and immune biomarker abnormalities associated with severe illness and mortality in coronavirus disease 2019 (COVID- 19): a metaanalysis. Clin Chem Lab Med. 2020, 58: 10.1515/cclm-2020-0369

16. Santoso A, Pranata R, Wibowo A, Al-Farabi MJ, Huang I, Antariksa B: Cardiac injury is associated with mortality and critically ill pneumonia in COVID- 19: a meta-analysis [published online ahead of print, 2020 Apr 19]. Am J Emerg Med. 2020, 10.1016/j.ajem.2020.04.052

17. Terpos E, Ntanasis-Stathopoulos I, Elalamy I, et al.: Hematological findings and complications of COVID19. Am J Hematol. 2020, 95:834-847. 10.1002/ajh.25829

18. Du RH, Liang LR, Yang CQ, et al.: Predictors of mortality for patients with COVID-19 pneumonia caused by SARS-CoV- 2: a prospective cohort study. Eur Respir J. 2020:2000524-2020. 10.1183/13993003.00524-2020

19. Wang Z, Yang B, Li Q, Wen L, Zhang R: Clinical features of 69 cases with coronavirus disease 2019 in Wuhan, China. Clin Infect Dis. 2020, 71:769-777. 10.1093/cid/ciaa272

20. Liu W, Tao ZW, Wang L, et al.: Analysis of factors associated with disease outcomes in hospitalized patients with 2019 novel coronavirus disease. Chin Med J (Engl). 2020, 133:1032-1038. 10.1097/CM9.0000000000000775

21. Levi M, Schultz M, van der Poll T: Sepsis and thrombosis. Semin Thromb Hemost. 2013, 39:559-566. 10.1055/s-0033-1343894

22. Tang N, Li D, Wang X, Sun Z: Abnormal coagulation parameters are associated with poor prognosis in patients with novel coronavirus pneumonia. J Thromb Haemost. 2020, 18:844-847. 10.1111/jth.14768

23. Zhang L, Yan X, Fan Q, et al.: D-dimer levels on admission to predict in-hospital mortality in patients with Covid-19. J Thromb Haemost. 2020, 18:1324-1329. 10.1111/jth.14859

24. Clerkin KJ, Fried JA, Raikhelkar J, et al.: COVID-19 and cardiovascular disease . Circulation. 2020, 141:16481655. 10.1161/CIRCULATIONAHA.120.046941

25. Shi S, Qin M, Shen B, et al.: Association of cardiac injury with mortality in hospitalized patients with COVID-19 in Wuhan, China. JAMA Cardiol. 2020, 5:802-810. 10.1001/jamacardio.2020.0950

26. Guo T, Fan Y, Chen M, et al.: Cardiovascular implications of fatal outcomes of patients with coronavirus disease 2019 (COVID-19). JAMA Cardiol. 2020, 5:e201017. 10.1001/jamacardio.2020.1017

27. Mao L, Jin H, Wang M, et al.: Neurologic manifestations of hospitalized patients with coronavirus disease 2019 in Wuhan, China. JAMA Neurol. 2020, 77:e201127. 10.1001/jamaneurol.2020.1127 
28. Tralhão A, Póvoa P: Cardiovascular events after community-acquired pneumonia: a global perspective with systematic review and meta-analysis of observational studies. J Clin Med. 2020, 9:414. 10.3390/jcm9020414

29. Avula A, Nalleballe K, Narula N, et al.: COVID-19 presenting as stroke. Brain Behav Immun. 2020, 87:115-

119. 10.1016/j.bbi.2020.04.077

30. Lodigiani C, Iapichino G, Carenzo L, et al.: Venous and arterial thromboembolic complications in COVID-19 patients admitted to an academic hospital in Milan, Italy. Thromb Res. 2020, 191:9-14. 10.1016/j.thromres.2020.04.024

31. Madjid M, Safavi-Naeini P, Solomon SD, Vardeny O: Potential effects of coronaviruses on the cardiovascular system: a review. JAMA Cardiol. 2020, 5:831-840. 10.1001/jamacardio.2020.1286

32. Aggarwal G, Lippi G, Michael Henry B: Cerebrovascular disease is associated with an increased disease severity in patients with coronavirus disease 2019 (COVID-19): a pooled analysis of published literature. Int J Stroke. 2020, 15:10.1177/1747493020921664

33. Guan WJ, Ni ZY, Hu Y, et al.: Clinical characteristics of coronavirus disease 2019 in China . N Engl J Med. 2020, 382:1708-1720. 10.1056/NEJMoa2002032

34. Guan WJ, Liang WH, Zhao Y, et al.: Comorbidity and its impact on 1590 patients with COVID-19 in China: a nationwide analysis. Eur Respir J. 2020, 55:2000547. 10.1183/13993003.00547-2020

35. Hu Y, Sun J, Dai Z, et al.: Prevalence and severity of corona virus disease 2019 (COVID- 19): A systematic review and meta-analysis. J Clin Virol. 2020, 127:104371. 10.1016/j.jcv.2020.104371

36. Epidemiology Working Group for NCIP Epidemic Response, Chinese Center for Disease Control and Prevention: The epidemiological characteristics of an outbreak of 2019 novel coronavirus diseases (COVID19) in China [Article in Chinese] . Zhonghua Liu Xing Bing Xue Za Zhi. 2020, 41:145-151. 10.3760/cma.j.issn.0254-6450.2020.02.003

37. Li J, Wang X, Chen J, Zhang H, Deng A: Association of renin-angiotensin system inhibitors with severity or risk of death in patients with hypertension hospitalized for coronavirus disease 2019 (COVID-19) infection in Wuhan, China. JAMA Cardiol. 2020, e201624. 10.1001/jamacardio.2020.1624

38. Wang Z, Chen Z, Zhang L, et al.: Status of hypertension in China: results from the China Hypertension Survey, 2012-2015. Circulation. 2018, 137:2344-2356. 10.1161/CIRCULATIONAHA.117.032380

39. Lippi G, Wong J, Henry BM: Hypertension in patients with coronavirus disease 2019 (COVID- 19): a pooled analysis. Pol Arch Intern Med. 2020, 130:304-309. 10.20452/pamw.15272

40. Zheng Z, Peng F, Xu B, et al.: Risk factors of critical \& mortal COVID-19 cases: A systematic literature review and meta-analysis. J Infect. 2020, 81:e16-e25. 10.1016/j.jinf.2020.04.021

41. Casqueiro J, Casqueiro J, Alves C: Infections in patients with diabetes mellitus: a review of pathogenesis . Indian J Endocrinol Metab. 2012, 16:27-36. 10.4103/2230-8210.94253

42. Tsalamandris S, Antonopoulos AS, Oikonomou E, et al.: The role of inflammation in diabetes: Current concepts and future perspectives. Eur Cardiol. 2019, 14:50-59. 10.15420/ecr.2018.33.1

43. Rask-Madsen C, King GL: Vascular complications of diabetes: mechanisms of injury and protective factors . Cell Metab. 2013, 17:20-33. 10.1016/j.cmet.2012.11.012

44. McDonald HI, Nitsch D, Millett ER, Sinclair A, Thomas SL: New estimates of the burden of acute community-acquired infections among older people with diabetes mellitus: a retrospective cohort study using linked electronic health records. Diabet Med. 2014, 31:606-614. 10.1111/dme.12384

45. Hussain A, Bhowmik B, do Vale Moreira NC: COVID-19 and diabetes: knowledge in progress . Diabetes Res Clin Pract. 2020, 162:108142. 10.1016/j.diabres.2020.108142

46. Roncon L, Zuin M, Rigatelli G, Zuliani G: Diabetic patients with COVID-19 infection are at higher risk of ICU admission and poor short-term outcome. J Clin Virol. 2020, 127:104354. 10.1016/j.jcv.2020.104354

47. Huang I, Lim MA, Pranata R: Diabetes mellitus is associated with increased mortality and severity of disease in COVID-19 pneumonia - A systematic review, meta-analysis, and meta-regression. Diabetes Metab Syndr. 2020, 14:395-403. 10.1016/j.dsx.2020.04.018

48. Yan Y, Yang Y, Wang F, et al.: Clinical characteristics and outcomes of patients with severe covid-19 with diabetes. BMJ Open Diabetes Res Care. 2020, 8:001343. 10.1136/bmjdrc-2020-001343

49. Zhu L, She ZG, Cheng X, et al.: Association of blood glucose control and outcomes in patients with COVID19 and pre-existing type 2 diabetes. Cell Metab. 2020, 31:1068-1077. 10.1016/j.cmet.2020.04.021 